\title{
Postharvest and anthochron of gladiolus floral stems produced in greenhouse under different seasons and irrigation levels
}

\author{
Pós-colheita e antocrono de hastes florais de gladíolo produzidas em \\ casa de vegetação sob diferentes épocas e níveis de irrigação
}

\author{
Jaqueline Jesus Santana dos Santos ${ }^{1}\left(\mathbb{D}\right.$, Rogério Gomes Pêgo ${ }^{1}\left(\mathbb{D}\right.$, Beatriz Rodrigues Monteiro Couto ${ }^{1} \mathbb{D}^{\mathbb{D}}$, \\ Rosária da Costa Faria Martins ${ }^{1}$, Daniel Fonseca de Carvalho ${ }^{2 *}(\mathbb{D}$
}

\begin{abstract}
'Universidade Federal Rural do Rio de Janeiro/UFRRJ, Departamento de Fitotecnia, Instituto de Agronomia, Seropédica, RJ, Brasil 2Universidade Federal Rural do Rio de Janeiro/UFRRJ, Departamento de Engenharia, Instituto de Tecnologia, Seropédica, RJ, Brasil ${ }^{*}$ Corresponding author: daniel.fonseca.carvalho@gmail.com

Received in April 22, 2021 and approved in June 2, 2021
\end{abstract}

\begin{abstract}
Cut flowers are delicate products whose quality and longevity depends on growing and postharvest conditions. The aim of the study was to evaluate the anthochron and the postharvest of gladiolus stems produced under different growing seasons and irrigation levels. The experiments were carried out in a greenhouse in the State of Rio de Janeiro (Brazil) during the winter/spring 2018 and autumn/ winter 2019 periods. A randomized block design with 5 replications was used, considering irrigation levels of $45 \%, 60 \%, 80 \%$ and $100 \%$ of the crop water requirement. Irrigation management was performed by the automatic irrigation controller, installed in the $100 \%$ irrigation level treatment. As they reached the harvest point, considered to be "showing the color" of the three basal florets, the floral stems were harvested, always in the morning, and immediately taken to the laboratory for standardization of size (75 cm). During the storage period, the stems were kept at a temperature of $25^{\circ} \mathrm{C}$, with the base immersed in a container with $300 \mathrm{~mL}$ of water. Fresh mass, water absorption, anthochron and longevity evaluations were performed daily, in addition to a visual evaluation, performed using a proposed senescence scale. The occurrence of severe water deficit during cultivation interferes with the fresh mass of the stems in postharvest and increases the opening speed of the flowers. The floral stems' longevity is reduced when gladiolus is produced under the $45 \%$ irrigation level. There are no significant differences in the longevity of flowers grown in the different seasons and the anthochron value is influenced by the water availability, being lower in the stems kept in field condition ( 0.70 to 0.80$)$ in comparison to the postharvest condition (0.83 to 0.92).
\end{abstract}

Index terms: Gladiolus x grandiflora Hort.; automated irrigation system; vase life; water deficit.

\section{RESUMO}

As flores de corte são produtos delicados cuja qualidade e longevidade dependem das condições de cultivo e pós-colheita. O trabalho foi desenvolvido objetivando-se avaliar o antocrono e a pós-colheita de hastes de gladíolo produzidas sob diferentes épocas de cultivo e níveis de irrigação. Os experimentos foram conduzidos em casa de vegetação no Estado do Rio de Janeiro (Brasil), durante os períodos de inverno/primavera de 2018 e outono/inverno de 2019. O delineamento experimental foi em blocos casualizados, com quatro níveis de irrigação $(45 \%, 60 \%, 80 \%$ e 100\% da necessidade hídrica da cultura) e 5 repetições. O manejo da irrigação foi realizado pelo acionador automático para irrigação, instalado no tratamento $100 \%$. A medida em que alcançavam o ponto de colheita, considerado como "mostrando a cor" dos três floretes basais, as hastes florais eram colhidas, sempre no período da manhã, e imediatamente levadas ao laboratório para padronização do tamanho $(75 \mathrm{~cm})$. Durante o armazenamento, as hastes foram mantidas à temperatura de $25{ }^{\circ} \mathrm{C}$, com a base imersa em recipiente contendo $300 \mathrm{~mL}$ de água. As avaliações de massa fresca, absorção de água, antocrono e longevidade foram realizadas diariamente, além de uma avaliação visual, realizada por meio de uma escala de senescência proposta. A ocorrência de déficit hídrico acentuado durante o cultivo interfere na massa fresca das hastes em póscolheita e aumenta a velocidade de abertura das flores. A longevidade das hastes florais é reduzida quando gladíolo é produzido com o nível de irrigação de $45 \%$. Não há diferenças significativas na longevidade das flores cultivadas nas diferentes estações e o valor do antocrono é influenciado pela disponibilidade de água, sendo menor nas hastes mantidas em condição de campo $(0,70$ a $0,80)$ em comparação à condição pós-colheita $(0,83$ a 0,92).

Termos para indexação: Gladiolus x grandiflora Hort.; sistema de irrigação automatizado; vida de vaso; déficit hídrico. 


\section{INTRODUCTION}

Among the most appreciated cut flowers on the market, gladiolus, also known as Palma-de-Santa-Rita, stands out for its robustness, vivacity and magnificence (Tomiozzo et al., 2019). For the fact that it is an easy-tomanage culture that has a short cycle and low production cost (Barbosa, 2011), it has become an excellent alternative for increasing income and diversifying production in family farming (Uhlmann et al., 2019). Its cultivation is predominantly carried out under field conditions and plant development and flower quality are affected by environmental factors such as temperature and light (Uhlmann et al., 2017; Schwab et al., 2018). Nevertheless, the species develops properly in protected environments (Paiva et al., 1999), either to meet thermal requirements, minimizing the effect of low temperatures in cold regions (Bosco et al., 2020), or to carry out controlled studies, evaluating the development of the plant in response to water replacement and nitrogen fertilization levels (Porto et al., 2014).

Cut flowers are considered delicate and perishable products, and their longevity depends on the conditions of cultivation, the appropriate moment of harvest and postharvest management (Dias-Tagliacozzo; Finger; Barbosa, 2005). Due to low heat loss inside greenhouses, the air temperature tends to be higher than in the outside (Bosco et al., 2020) causing the length of the development cycle to be shorter. Despite this, Islam and Haque (2011) observed better development and a greater number of florets per spike in gladiolus plants produced under a polyethylene tunnel when compared to open-air plants. As in the postharvest phase it is not possible to improve the quality of the product in relation to the moment of harvest, the management of the crop must be efficient, meeting the water, nutritional and edaphoclimatic needs, producing high quality flowers (Bastug et al., 2006).

When water deficit is applied throughout the growing cycle, some plants suffer a reduction in water potential causing stomatal closure, decreasing the rate of carbon dioxide assimilation and, consequently, photosynthesis (Taiz et al., 2017). The reduction in the photosynthetic rate limits the production of carbohydrates and inhibits the growth of the stem and the cellular expansion of many ornamental plants (Toscano; Ferrante; Romano, 2019). Gladiolus plants that grow under intense water deficits may have smaller floral stems and number of flowers produced (Demirel; Camoglu; Akcal, 2018), affecting the ornamental quality and the marketing of these flowers (Das et al., 2015).
Considering that the quality of the gladiolus floral stems is influenced by the adequate availability of water provided by irrigation, it can be inferred that the longevity of flowers can also be longer when compared to flowers produced under water deficit. The vase life of a cut gladiolus flower is short due to physiological and biochemical mechanisms that induce senescence (Hassan; Fetouh, 2019; Mohibe et al., 2020). However, no approach on the effects of water deficit on its longevity has been previously documented.

For gladiolus, the market demands the sale of stems with flowers still closed, when the first three floral buds show the corolla color, traditionally called by producers as the "button showing the color" (Barbosa, 2011; Schwab et al., 2015). This harvest point is recommended because the flowers are very fragile and can be easily damaged if handled or transported when they are opened (Barbosa, 2011).

Due to the short period of marketing of the gladiolus floral stems, the production planning becomes essential, as well as the harvesting and distribution logistics that depend on the flowers opening speed (Schwab et al., 2017). Anthochron is a term used to define the time interval between the opening of successive flowers in an inflorescence (Schwab et al., 2014) and it is an important characteristic to evaluate in species that have spiketype flowers. For some commercial cut flowers, more specifically for the gladiolus, whose harvest of the floral stems is done with the florets still closed, the definition of anthochron allows to understand the development of the plant during the reproductive phase and determine its postharvest life (Streck; Schwab, 2016). Its determination in water deficit conditions allows to broaden the understanding of how irrigation management can influence the gladiolus floral opening rate.

The gladiolus' demand follows the sales pattern of most flowers, and it is important that high-quality flowers are produced throughout the year (Paiva et al., 2020). It is especially important that the water volume is adjusted to the crop, producing high quality stems that can last longer, increasing marketing efficiency (Santos et al., 2020). Considering that the production of gladiolus flowers is influenced by the growing season (Schwab et al., 2014; Schwab et al., 2017) and that the longevity of flowers is reduced when the plants are grown under stress, we hypothesize that the gladiolus floral stems present lowest longevity when produced under deficit irrigation and that they are also affected by the conditions of the growing period. Therefore, the objective of this work was to evaluate the anthochron and the postharvest period of gladiolus stems produced 
in greenhouse under different growing seasons and irrigation levels with automated management.

\section{MATERIAL AND METHODS}

\section{Production of stems in greenhouse}

Floral stems of gladiolus were produced in a greenhouse installed in Seropédica (Rio de Janeiro, Brazil) in two growing seasons. The winter/spring cultivation was carried out in the period from September $7^{\text {th }}$ to November $27^{\text {th }}$ of 2018 and the autumn/winter cultivation from April $12^{\text {th }}$ to July $4^{\text {th }}$ of 2019 . During the winter/spring cycle, the reproductive phase of the stems occurred under higher average temperatures $\left(20.5\right.$ to $\left.41.5^{\circ} \mathrm{C}\right)$ than those recorded for the autumn/winter cycle (18.3 to 40.7 ${ }^{\circ} \mathrm{C}$ ), which explains the more significant accumulation of degree-days in the winter/spring cycle (Santos et al., 2020). The maximum and minimum values recorded for relative humidity (RH\%) in the autumn/winter production were $89.8 \%$ and $21.2 \%$, respectively, while in the winter/ spring production, it was $88.8 \%$ and $18.7 \%$, respectively. The monitoring of meteorological conditions inside the greenhouse was carried out via a weather station (WatchDog 2000 Series SPECTRUM, Technologies Inc.).

The greenhouse was $35.0 \mathrm{~m}$ long and $8.0 \mathrm{~m}$ wide, it had $2.5 \mathrm{~m}$ of central height and it was covered with 100-micron thick transparent plastic, without any cooling or artificial temperature control system. The plants were grown in $11.0 \mathrm{~L}$ pots containing substrate composed of a mixture of bovine manure and sandy and clayey soil materials, in the proportion of 1:2:2 (by volume). The analysis of the substrate used presented the following chemical characteristics: $\mathrm{pH} 6.2 ; 0.13$ cmolc dm ${ }^{-3} \mathrm{Na}^{2+}$; $4.5 \mathrm{cmolc} \mathrm{dm}^{-3} \mathrm{Ca}^{2+} ; 1.9 \mathrm{cmolc} \mathrm{dm}^{-3} \mathrm{Mg}^{2+} ; 122 \mathrm{mg} \mathrm{dm}^{-3} \mathrm{P}$; $83 \mathrm{mg} \mathrm{dm}^{-3} \mathrm{~K}^{+} ; \mathrm{V}$ value $=80 \%$ for the first crop; and $\mathrm{pH}$ 5.8; $0.1 \mathrm{cmolc} \mathrm{dm}^{-3} \mathrm{Na}^{2+} ; 3.8 \mathrm{cmolc} \mathrm{dm}{ }^{-3} \mathrm{Ca}^{2+} ; 1.6 \mathrm{cmolc}$ $\mathrm{dm}^{-3} \mathrm{Mg}^{2+} ; 134 \mathrm{mg} \mathrm{dm}^{-3} \mathrm{P} ; 84 \mathrm{mg} \mathrm{dm}^{-3} \mathrm{~K}^{+} ; \mathrm{V}$ value $=76 \%$ for the second crop.

The gladiolus cv. Amsterdam was used, which has white flowers and, approximately, 75 days of cycle. Vernalized medium-sized bulbs (circumference from 12 to $14 \mathrm{~cm}$ ) were purchased from Terra Viva and planted in a triangular arrangement, with a spacing of $10 \mathrm{~cm}$ between bulbs and 10 cm deep (Ahmad et al., 2013, Santos et al., 2020).

The pots were drip irrigated using spaghetti microtubes (PDAEXT001000354/PLASNOVA) with an average diameter of $0.8 \mathrm{~mm}$ and lengths of $80,60,35$ and $20 \mathrm{~cm}$, corresponding to discharges of $2.6 ; 3.4 ; 4.5$ and $5.7 \mathrm{~L}$ $\mathrm{h}^{-1}$, respectively, at a pressure of $20 \mathrm{kPa}$. The uniformity tests indicated a uniformity coefficient above $95 \%$. Thereafter, irrigation levels (IL) were defined and corresponded to $45 \%$ (L1), $60 \%$ (L2), $80 \%$ (L3) and $100 \%$ (L4) of the crop water requirement. Irrigation management was carried out using two automatic controllers for irrigation (Medici et al., 2010), whose sensors were installed in the center of two pots at $10 \mathrm{~cm}$ depth in the control treatment (L4). Thus, when the system was activated, all pots were irrigated simultaneously, with volumes of water corresponding to the respective flow rates of the emitters (treatments). In total, 5.24, 6.68, 8.65 and $10.81 \mathrm{~L}$ (winter/spring cycle) and 4.91, 6.58, 8.25 and $10.25 \mathrm{~L}$ of water per plant (autumn/winter cycle) were applied for the $45 \%$ (L1), $60 \%$ (L2), $80 \%$ (L3) and $100 \%$ (L4) treatments, respectively (Santos et al., 2020).

\section{Postharvest evaluation}

The floral stems were harvested, always in the morning, as they reached the harvest point, with the 3 basal florets starting to open, a characteristic established by the R2 stage of the phenological scale of gladiolus (Schwab et al., 2015). After harvesting, the stems were immediately placed in a container with water to prevent dehydration during transport and transferred to the laboratory. At the harvest time, no stems smaller than $75 \mathrm{~cm}$ were observed in the different cultivation cycles. The harvested stems were classified and $81.7 \%$ and $92.5 \%$ of high-quality stems (class 90 or 110) were obtained in the winter/spring and autumn/winter cultivations, respectively. In the laboratory, the stems went through a standardization to ensure uniform size $(75 \mathrm{~cm})$ and adequacy to the quality criteria for marketing (Veiling Holambra, 2019). It was used to homogenize the lengths for postharvest analysis, regardless of the quality class obtained at the time of harvest.

During the postharvest analysis period in a laboratory, the environment temperature was maintained at, approximately, $25^{\circ} \mathrm{C}$. The plants were kept on wooden supports, in which each stem was allocated in a $10 \times 10 \mathrm{~cm}$ mesh. Visual and analytical assessments on the selected stems were performed daily.

\section{Longevity}

The stems were kept in containers with university campus supply water and their longevity was evaluated and expressed in days of vase life, from the harvest day until the moment of complete senescence of $50 \%$ of the flowers in the stalk, or until the occurrence of a break in the floral stem due to loss of turgor. Thus, to evaluate the quality of the inflorescences during vase life, a senescence scale was proposed. 


\section{Water absorption}

The stems were placed in containers with $300 \mathrm{~mL}$ of water, which was weighed, discarded and replaced daily. Water absorption was calculated according to the methodology described by Van Doorn, Abadie and Belde (2002) and Vieira et al. (2012), using Equation 1:

$\mathrm{V}=\frac{(\mathrm{WMi}-\mathrm{WMf})}{\mathrm{FMS}_{\mathrm{i}}}$

in which: $\mathrm{V}$ - water absorption $\left(\mathrm{mg} \cdot \mathrm{g}^{-1} \mathrm{FM}\right) ; \mathrm{FM}$ - fresh mass of stem (g); WMi - initial water mass (g); WMffinal water mass $(\mathrm{g})$; and $\mathrm{FMS}_{\mathrm{i}}$ - final fresh mass of stem in each day $(\mathrm{g})$.

\section{Fresh mass variation}

The stems were weighed daily, and the fresh mass variation was determined according to Van Doorn, Abadie and Belde (2002), using Equation 2:

$\mathrm{FMV}=\frac{(\mathrm{Mf} \times 100)}{\mathrm{Mi}}$

In which: FMV - fresh mass variation (\%); Mf - final mass of stem $(\mathrm{g}) ; \mathrm{e} \mathrm{Mi}$ - initial mass of stem $(\mathrm{g})$.

\section{Scale of senescence scores of floral stems of gladiolus}

The scale of senescence scores was proposed relating the flower opening dynamics during the longevity period (Figure 1).

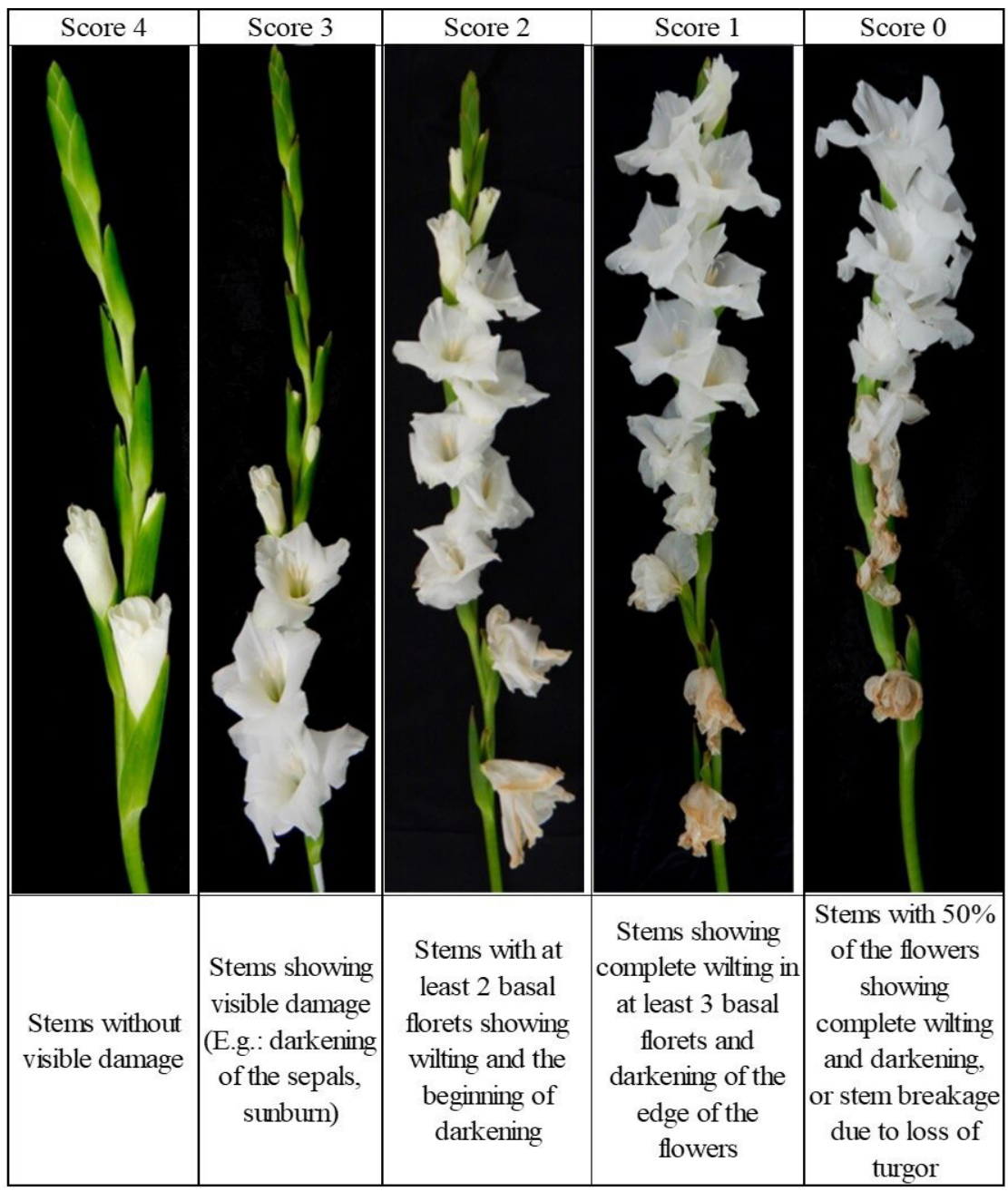

Figure 1: Senescence scale for assessing the longevity of gladiolus cv. Amsterdam inflorescences. 


\section{Anthochron}

For the anthochron analysis, evaluations were carried out in two different conditions: in a greenhouse and in laboratory, during the postharvest longevity assessment. However, in the greenhouse, it was evaluated only in the winter/spring cultivation. The anthochron of the floral stems in the greenhouse was determined by the daily count of the florets which were opening since the moment the plants reached the point of harvest, while in the postharvest condition, the daily count of the flowers that were opening was performed since the harvest was carried out until the moment the stems reached the score 0 of the proposed scale. The anthochron evaluation was performed on 5 stems per plot, totalizing 25 stems per treatment. The evaluation was carried out by observing the floral opening, considering as an open flower the moment in which the anthers were visible to the evaluator. It was estimated according to the methodology proposed by Schwab et al. (2014), as the inverse of the angular coefficient of the linear regression between the number of opened florets and the opening time of florets, as long as the coefficient of determination is greater than 0.90 .

\section{Experimental design and statistical analysis}

The experimental design during the production of the stems was randomized blocks with 5 blocks composed of 4 plots, one from each treatment (IL). Each experimental unit (plot) was composed of 4 pots with 3 plants, totalizing 12 plants per plot. For the postharvest evaluation, 6 stems were harvested per plot in the winter/spring cultivation and 4 stems in the autumn/winter cultivation, totalizing 30 and 20 stems per treatment, respectively. The reduction in the number of stems in the autumn/winter cycle of 2019 was due to the incidence of fusariosis in $8.8 \%$ of the total plants in the experiment, which ended up in some plants that did not produce the floral stem and others that were not evaluated. In addition, in the autumn/winter cultivation, 5 stems per plot were left in the pots to evaluate the anthochron.

Data were subjected to the homoscedasticity test and, after being checked for normality, to analysis of variance at $5 \%$ probability level $(\mathrm{p} \leq 0.05)$ by $\mathrm{F}$ test. For water absorption, fresh weight variation and the scale scores, the average values observed in the replications were calculated. Longevity data were subjected to the analysis of variance by the $F$ test $(p \leq 0.05)$ and the means were compared by the Tukey's test $(\mathrm{p} \leq 0.05)$. Linear regression analysis was also performed for the anthochron variable, according to Schwab et al. (2014), and the Student's t test $(p \leq 0.05)$ was used to assess the quality of the fit.

\section{RESULTS AND DISCUSSION}

\section{Anthochron of floral stems in the greenhouse}

There was a reduction in the floral opening rate of gladiolus plants, cv. Amsterdam, submitted to water deficit in the greenhouse. The opening rate followed a linear trend and the anthochron was $0.80 ; 0.75 ; 0.70$ and 0.71 days/ floret, respectively, for the treatments with $45,60,80$ and $100 \%$ of the applied volume of water (Figure 2).

In cut gladiolus, the anthochron depends on the cultivar and on the period of cultivation; floral stems of cv. Amsterdam grown throughout the year can present significant difference between the maximum and minimum anthochron value (floret per day) of 1.39 and 0.65 , respectively; this is equivalent to a 0.74 floret variation per day (Schwab et al., 2014). The floral opening rate is an important characteristic to be evaluated in gladiolus because the cut flower stems are commercialized when they are still closed, and they complete their opening during the postharvest life (Barbosa, 2011). Therefore, it is essential to understand how the crop management can affect the stems' physiology in the production phase and in postharvest.

Some studies report that the gladiolus anthochron of the cvs. 'Amsterdam', 'Peter Pears', 'Rose Friendship', and 'Jester' is influenced by environmental characteristics such as temperature and radiation during flowering; to these gladiolus cultivars, the base temperature for opening the florets is $6^{\circ} \mathrm{C}$ and the optimum and maximum temperatures are $22.5^{\circ} \mathrm{C}$ and $35^{\circ} \mathrm{C}$, respectively (Schwab et al., 2014; Muttoni, et al., 2017; Schwab et al., 2017). The results presented in this study demonstrate that the lower water availability during the cultivation also negatively affects the anthochron. Considering that the longevity of flowers depends on the quality of the floral stems at the time of harvest, water deficit conditions during the production of the stems can affect their longevity.

\section{Postharvest of cut flower stems}

The absorption of water by the stems decreased as a function of the days after harvest, with different variation among treatments. There was greater water absorption on the first day, with a reduction on the subsequent days. This trend occurred in all treatments, but there was a higher initial absorption in the treatment of $45 \%$, in both cycles (Figure 3A, B). With a greater water deficit, the floral stems become more dehydrated, and after hydration during postharvest, they absorb more water to promote the opening of the flowers and keep their fresh mass. 

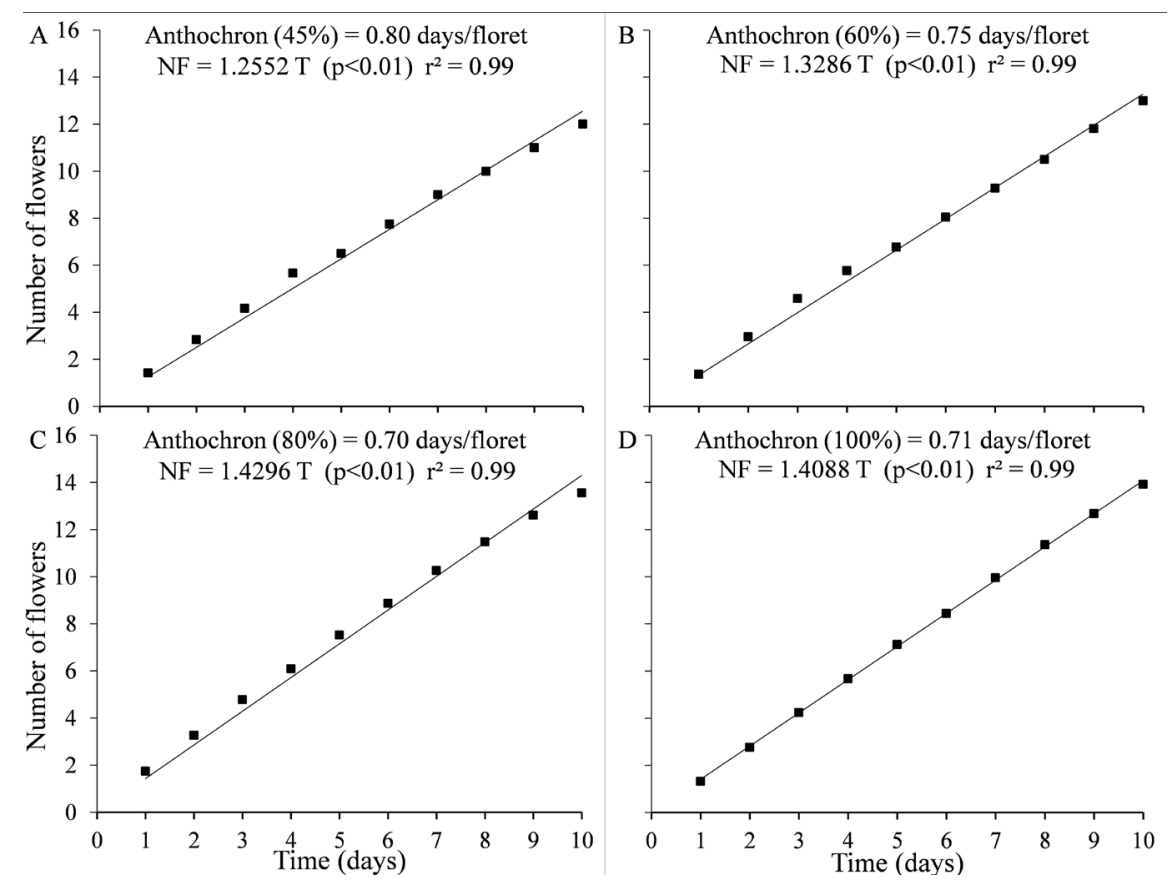

Figure 2: Flower opening rate (anthochron) of gladiolus cv. Amsterdam, evaluated in plants grown in the greenhouse under the irrigation levels of $45 \%$ (A), $60 \%$ (B), $80 \%$ (C) and $100 \%$ (D), in the autumn/winter cultivation.
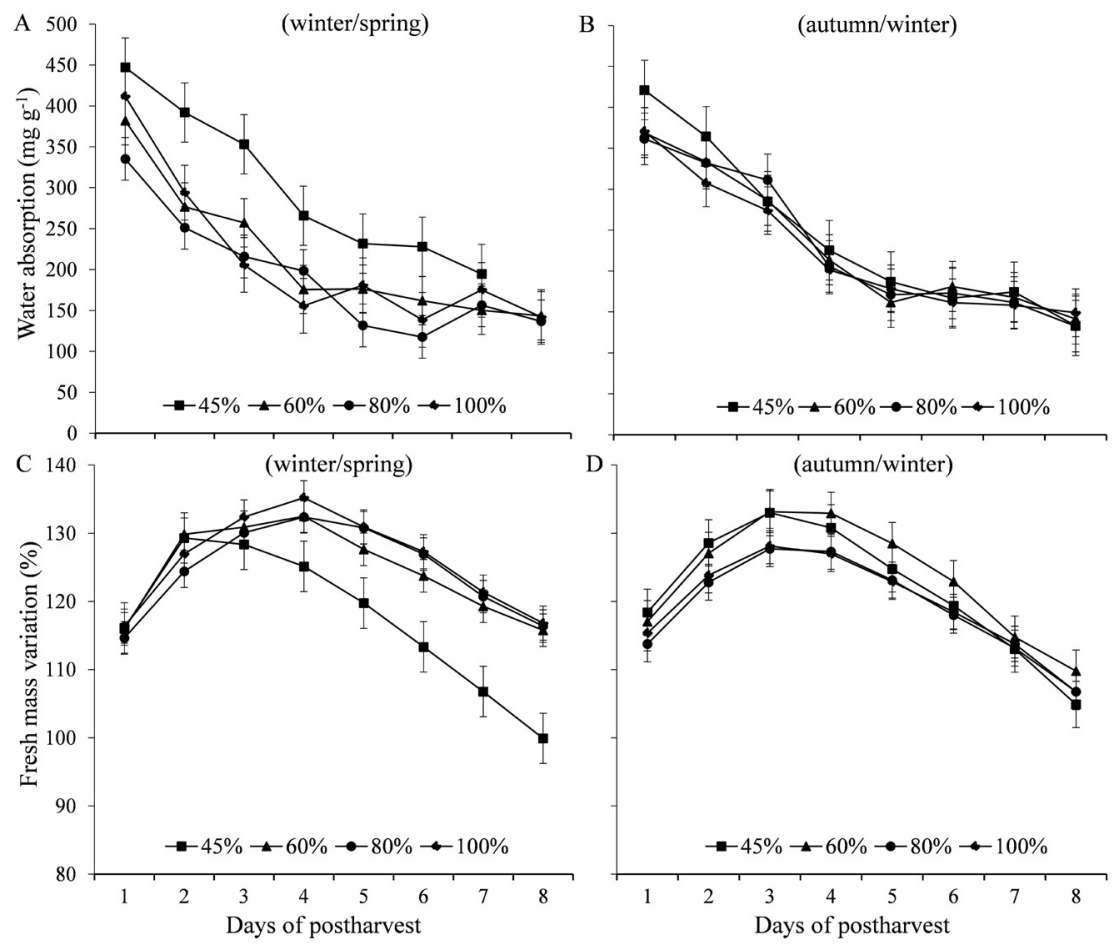

Figure 3: Water absorption ( $\mathrm{mg} \mathrm{g}^{-1}$ fresh mass of stem) and fresh mass variation (\%) of gladiolus stems, cv. Amsterdam, grown under different irrigation levels in the winter/spring cycle of 2018 ( $a$ and $c$ ) and in the autumn/ winter cycle of 2019 ( $b$ and d), respectively. Bars represent standard error. 
Floral stems grown under lower irrigation levels (45\% and 60\%) showed, in the first postharvest days, a greater increase of fresh mass when compared to those that was grown in the highest irrigation levels $(80 \%$ and $100 \%$ ), in both cycles. Throughout the storage period, the fresh mass decreased in all treatments, but earlier in the floral stems grown with a lower level of irrigation (L1) and in the winter/spring cycle when in comparison to the other treatments and cycle. In this case, the reduction in fresh weight occurred since the third day of storage, while for the other treatments this reduction was observed since the fifth day. In the autumn/winter cultivation, the fresh mass began to decrease for all treatments since the fourth day, as occurred for the treatments of higher water deficits $(45 \%$ and $60 \%$ ) in the previous cultivation.

The fresh mass of the gladiolus floral stems increases on the first days due to the absorption of water to promote initial rehydration. However, studies indicate that after the first days of postharvest there is a loss of mass of the floral stems, mainly due to natural transpiration and low hydraulic conductance in the xylem, considered as the main causes of loss of turgor that contributes to the deterioration of the product, causing visual changes (Silva et al., 2019; In et al., 2017).

The turgor of cut flowers depends on the balance between the use of water and its supply; and some physiological processes of absorption, transport, loss of water and the ability of tissues to retain it are also involved in their water balance (Dias-Tagliacozzo; Finger; Barbosa, 2005). Loss of mass can be caused by transpiration, by the decrease in water absorption that can occur due to the obstruction of the xylem by microorganisms or by genetically determined factors (Pietro et al., 2012).

In the postharvest evaluation (Figure 4), the anthochron was $0.85,0.89,0.83$, and 0.91 in the winter/spring cycle and $0.83,0.92,0.92$, and 0.89 in the autumn/winter cycle.

The anthochron of cut flowers during postharvest in laboratory was higher than in the greenhouse (Figure 2), with the florets opening since the first day, that is, the day after the harvest (time zero). This result suggests that the opening of the florets in the greenhouse occurs more quickly, probably due to the maintenance of the supply of nutrients and carbohydrates to the stems, as they are still linked to the plant, unlike the stems in postharvest that received only water supply.
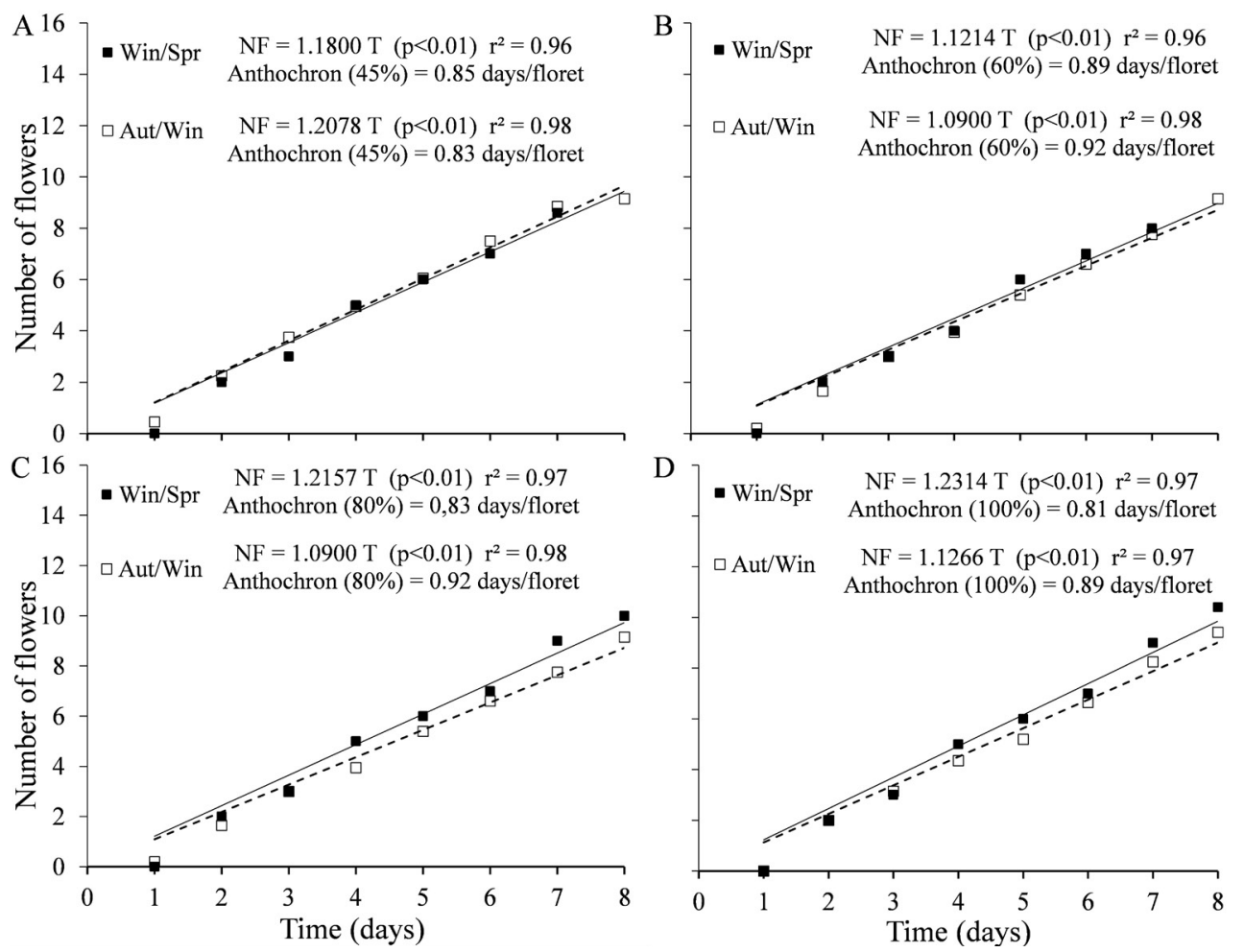

Figure 4: Flower opening rate (anthochron) of gladiolus, cv. Amsterdam, evaluated in postharvest plants of the treatments of $45 \%$ (a), $60 \%$ (b), $80 \%$ (c) and $100 \%$ (d) irrigation levels, in the winter/spring and autumn/winter cultivations. 
The floral opening is related to cell expansion and requires water and energy absorption (Mattos et al., 2018). Therefore, the greater water supply to the stems during cultivation promotes a faster floral opening compared to the plants grown under water deficit. The sucrose levels of the floral stems kept in the greenhouse may have contributed to the osmotic potential and maintenance of plant turgor, in addition to being a substrate for maintaining respiration, which contributes to the higher rate of floral opening (Hussen; Yassin, 2013).

Stems cultivated with a lower irrigation level opened the flowers more slowly in the greenhouse when compared to those that received a greater amount of water (Figure 2). However, in the postharvest evaluation, the result was reversed, and the opening of the florets happened faster in the stems that received less water and slower in those that received more volume of water. These results indicate that the opening of floral stems in the postharvest of gladiolus is associated with water availability during cultivation, and it is strongly influenced by the mechanical action of hydration at the beginning of the postharvest phase, especially of flowers grown under water deficit.

For the stems of the treatment of $45 \%$ of the applied volume of water, lower values of anthochron during postharvest imply a shorter marketing period for the producer. When the flowers open more quickly and the distribution site is far from the production site, the stems can arrive with more advanced maturation than expected commercially, besides the possibility of greater risk of mechanical damage to the flowers during transport, when their marketing is done at local fairs.

The water supply is one of the factors that affect the anthochron due to the interference in the production and the translocation of carbohydrates in the plant during flowering (Streck; Schwab, 2016). Schwab et al. (2014) were the first to use the term "anthochron" for gladiolus and found values of 0.99 and 1.27 days per floret, for the cv. Amsterdam grown in Rio Grande do Sul, respectively, in spring and late summer. The values found in the present study are lower even for the stems that received $100 \%$ of the crop's water requirement, indicating that in tropical conditions, such as in Seropédica (Rio de Janeiro), the opening of the stem's flowers happens faster than in subtropical regions.

The floral opening in the postharvest period is an important factor from a commercial point of view, because the higher the opening speed, the faster this stem needs to get to the place of sale to avoid loss of quality.

The first signs of senescence on the stems were the darkening of the sepals, according to the scale of scores, which started to appear since the second day of evaluation on all treatments in the winter/spring cycle (Figure 5A). Since this day, the score dropped from 4 to 3 and the stems received the same scores, except for the treatment of $45 \%$ of the applied volume, in which the visual quality decreased more quickly, reaching the minimum score on the seventh day.

The stems grown with 80 and $100 \%$ of the water volume applied in the autumn/winter cycle (Figure 5B) remained with a maximum score until the third day of evaluation, decreasing from this point and reaching a minimum score on the eighth day, when the stems already had at least $50 \%$ of the flowers completely wilted. The stems grown in autumn/winter remained with maximum quality for a longer time than the ones obtained from winter/spring, with the exception of the treatments of 45 and $60 \%$ of the applied volume, which in the autumn/winter cultivation started to drop in quality on the second day (Figure 5B).
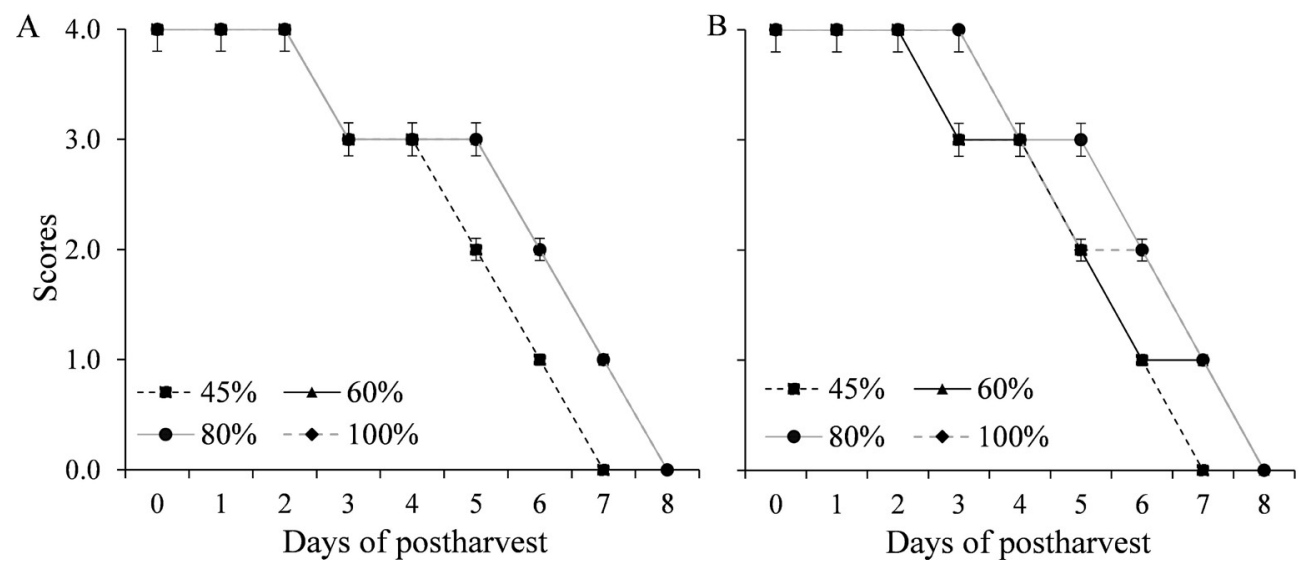

Figure 5: Scores received by gladiolus floral stems, cv. Amsterdam, during postharvest evaluation in the winter/ spring (a) and autumn/winter (b) cultivations. Bars represent standard error. 
The longevity of the floral stems was significantly influenced by the different irrigation levels, but there was no influence of the growing season (Table 1). The stems' vase life reached 8 days in both cycles. In the winter/spring cultivation, the longest vase life was obtained in the stems produced with $100 \%$ of the applied volume ( 8 days), not differing statistically from the treatments with 60 and $80 \%$ of the water volume.

Table 1: Longevity (days) of gladiolus Cv. Amsterdam floral stems grown under different irrigation levels.

\begin{tabular}{ccc}
\hline \multirow{2}{*}{ Irrigation level (\%) } & \multicolumn{2}{c}{ Longevity (days) } \\
\cline { 2 - 3 } & Winter/spring & Autumn/winter \\
\hline 45 & $7.0 \mathrm{Ab}$ & $7.6 \mathrm{Aa}$ \\
60 & $7.4 \mathrm{Aab}$ & $7.8 \mathrm{Aa}$ \\
80 & $7.8 \mathrm{Aa}$ & $8.2 \mathrm{Aa}$ \\
100 & $8.0 \mathrm{Aa}$ & $8.2 \mathrm{Aa}$ \\
\hline \multicolumn{3}{c}{4.63} \\
\hline
\end{tabular}

*Means followed by the same capital letter in the lines and lowercase letter in the columns do not differ statistically from each other by the Tukey's test, at 5\% probability level.

Stems produced with $45 \%$ of irrigation level had a reduction in vase life of 1 day when compared to the ones produced under higher irrigation levels in the winter/spring period. This result suggests that when gladiolus plants are grown with a water deficit of $55 \%$ (promoted by the $45 \%$ irrigation level), not only the quantitative parameters are negatively affected but also the postharvest longevity of the floral stems. However, the irrigation levels did not affect the floral stem's longevity when the cultivation was done during the autumn/winter period.

The cut flowers cultivation under water deficit causes a reduction in the photosynthetic rate, and it results in less storage of carbohydrates in the plant. The content of carbohydrates stored in the cut flower during cultivation is important to maintain physiological processes such as floral opening and plant respiration in the postharvest phase, assisting to maintain longevity (Reid; Jiang, 2012; Van der Meulen-Muisers et al., 2001). Therefore, its depletion can accelerate the process of plant deterioration (Sonego; Brackmann, 1995). When the plant has a low carbohydrate reserve, this depletion in the postharvest period occurs faster and can influence the plant's vase life.

In the autumn/winter period, longevity did not differ from the winter/spring cultivation, suggesting that the growing season does not influence the stem's postharvest, which varies from 7 to 8 days. The same result was found by Hassan and Fetouh (2019), who studied the longevity of gladiolus stems treated with moringa extract and observed that the vase life of the stems reached 8 days in the untreated plants. A shorter postharvest longevity implies lower quality of the product and a smaller marketing window for the producer.

\section{CONCLUSIONS}

The flower stems' longevity is reduced when gladiolus is irrigated with $45 \%$ of the crop water requirement. There are no significant differences in the longevity of flowers grown in the different seasons (winter/ spring and autumn/winter cycle) in the environmental conditions presented in this work. The anthochron values are lower in stems kept in field condition $(0.70$ to 0.80$)$ than those observed in postharvest condition ( 0.83 to 0.92 ), being influenced by water availability.

\section{REFERENCES}

AHMAD, I. et al. Humic acid and cultivar effects on growth, yield, vase life, and corm characteristics of gladiolus. Chilean Journal of Agricultural Research, 73(4):339-344, 2013.

BARBOSA, J. G. Palma-de-Santa-Rita (Gladíolo): Produção comercial de flores e bulbos. Viçosa: Editora da UFV, 2011. 113p.

BASTUG, R. et al. The effects of drip irrigation on flowering and flower quality of glasshouse gladiolus plant. Agricultural Water Management, 81(1-2):132-144, 2006.

BOSCO, L. C. et al. Cultivo de gladíolo no inverno em ambiente protegido na Mesorregião Serrana de Santa Catarina. Agrometeoros, 27(1):191-198, 2020.

DAS, R. et al. Impact of water deficit stress on biomass production of different gladiolus cultivars under rainfed condition. Journal of Floriculture and Landscaping, 1(1):10-13, 2015.

DEMIREL, K.; CAMOGLU, G.; AKCAL, A. Effect of water stress on four varieties of gladiolus. Fresenius Environmental Bulletin, 27(12A):9300-9307, 2018.

DIAS-TAGLIACOZZO, G. M.; FINGER, F. L.; BARBOSA, J. G. Fisiologia pós-colheita de flores de corte. Ornamental Horticulture, 11(2):89-99, 2005.

HASSAN, F. A. S.; FETOUH, M. I. Does moringa leaf extract have preservative effect improving the longevity and postharvest quality of gladiolus cut spikes? Scientia Horticulturae, 250:287-293, 2019 
HUSSEN, S.; YASSIN, H. Review on the impact of different vase solutions on the postharvest life of rose flower. International Journal of Agricultural Research and Review, 1(2):13-17, 2013.

IN, B. C. et al. Relationships between the longevity, water relations, ethylene sensitivity, and gene expression of cut roses. Postharvest Biology and Technology, 131(1):74-83, 2017.

ISLAM, M. S.; HAQUE, A. F. M. E. Performance of gladiolus under protected cultivation in the rainy season. Bangladesh Journal of Agricultural Research, 36(2):285-290, 2011.

MATTOS, D. G. et al. Starch and total soluble sugar content in torch ginger postharvest. Ornamental Horticulture, 24(4):435-442, 2018.

MEDICl, L. O. et al. Automatic controller to water plants. Scientia Agricola, 67(6):727-730, 2010.

MOHIBE, N. et al. Effect of chemicals treatment on keeping quality and vase life of gladiolus flowers. Alexandria Science Exchange Journal, 41(2):285-293, 2020.

MUTTONI, M. et al. Cardinal temperatures for planting-emergence phase in gladiolus. Ciência Rural, 47(10):e20160824, 2017.

PAIVA, P. D. O. et al. Cultura do gladíolo. Lavras: UFLA Departamento de Agricultura, 1999. 12p.

PAIVA, P. D. O. et al. Flower and ornamental plant consumers profile and behavior. Ornamental Horticulture, 26(3):333-345, 2020.

PIETRO, J. D. et al. Qualidade de rosas de corte tratadas com produtos naturais. Ciência Rural, 42(10):1781-1788, 2012.

PORTO, R. A. et al. Effects of water replacement levels and nitrogen fertilization on growth and production of gladiolus in a greenhouse. Agricultural Water Management, 131:50-56, 2014.

REID, M. S.; JIANG, C. Z. Postharvest biology and technology of cut flowers and potted plants. Horticultural Reviews, 40:1 54,2012

SANTOS, J. J. S. et al. Evaluation of water requirement, commercial quality, and yield response factor of gladiolus produced with automated irrigation in different growing periods. Ciência e Agrotecnologia, 44:e017220, 2020.

SCHWAB, N. T. et al. Aplicabilidade do termo antocrono para representar a velocidade de abertura de flores em inflorescência. Pesquisa Agropecuária Brasileira, 49(9):657-664, 2014.

SCHWAB, N. T. et al. Duration of cycle and injuries due to heat and chilling in gladiolus as a function of planting dates. Ornamental Horticulture, 24(2):163-173, 2018.
SCHWAB, N. T. et al. Temperatura base para abertura de floretes e antocrono em gladíolo. Revista Ceres, 64(6):616621, 2017.

SCHWAB, N. T. et al. A phenological scale for the development of gladiolus. Annals of Applied Biology, 166(3):496-507, 2015.

SILVA, C. G. D. et al. Postharvest durability of Heliconiaceae evaluated in a controlled environment in Mato Grosso state, Brazil. Ornamental Horticulture, 25(1):80-86, 2019.

SONEGO, G.; BRACKMANN, A. Conservação pós-colheita de flores. Ciência Rural, 25(3):473-479, 1995.

STRECK, N. A.; SCHWAB, N. T. O antocrono como unidade básica do desenvolvimento floral. Pesquisa Agropecuária Brasileira, 51(8):899-904, 2016.

TAIZ, L. et al. Fisiologia e desenvolvimento vegetal. 6.ed., Porto Alegre: Artmed Editora, 2017. 888p.

TOMIOZZO, R. et al. How to produce gladiolus corms? Ornamental Horticulture, 25(3):299-306, 2019.

TOSCANO, S.; FERRANTE, A.; ROMANO, D. Response of mediterranean ornamental plants to drought stress. Horticulturae, 5(1):1-20, 2019.

UHLMANN, L. O. et al. Gladiolus as an alternative for diversification and profit in small rural property. Ornamental Horticulture, 25(2):200-208, 2019.

UHLMANN, L. O. et al. PhenoGlad: A model for simulating development in Gladiolus. European Journal of Agronomy, 82(Part A):33-49, 2017.

VAN DER MEULEN-MUISERS, J. J. et al. Postharvest flower development in Asiatic hybrid lilies as related to tepal carbohydrate status. Postharvest Biology and Technology, 21(2):201-211, 2001.

VAN DOORN, W. G.; ABADIE, P.; BELDE, P. J. Alkylethoxylate surfactants for rehydration of roses and Bouvardia flowers. Postharvest Biology and Technology, 24(3):327333, 2002.

VEILING HOLAMBRA. Critérios de classificação: Gladíolo corte. 2019. 4p. Departamento de Qualidade e PósColheita. Available in: <http://veiling.com.br/uploads/ padrao/gladiolo-fc.pdf>. Access in: February, 26, 2021.

VIEIRA, L. M. et al. Vascular occlusion and water relations in cut snapdragon flowers. Acta Horticulturae, 937:179184, 2012. 